\title{
Short communication: Estimation of the financial benefit of using Jersey milk at different inclusion rates for Cheddar cheese production using partial budgeting
}

\author{
J. H. Bland, ${ }^{* 1}$ A. P. Bailey,† A. S. Grandison, ${ }^{*}$ and C. C. Fagan* \\ *Department of Food and Nutritional Sciences, University of Reading, Whiteknights, PO Box 226, Reading, RG6 6AP, United Kingdom \\ †School of Agriculture, Policy and Development, University of Reading, Whiteknights, PO Box 237, Reading, RG6 6AR, United Kingdom
}

\begin{abstract}
Partial budgeting was used to estimate the net benefit of blending Jersey milk in Holstein-Friesian milk for Cheddar cheese production. Jersey milk increases Cheddar cheese yield. However, the cost of Jersey milk is also higher; thus, determining the balance of profitability is necessary, including consideration of seasonal effects. Input variables were based on a pilot plant experiment run from 2012 to 2013 and industry milk and cheese prices during this period. When Jersey milk was used at an increasing rate with Holstein-Friesian milk (25, 50, 75, and 100\% Jersey milk), it resulted in an increase of average net profit of $3.41,6.44,8.57$, and 11.18 pence per kilogram of milk, respectively, and this additional profit was constant throughout the year. Sensitivity analysis showed that the most influential input on additional profit was cheese yield, whereas cheese price and milk price had a small effect. The minimum increase in yield, which was necessary for the use of Jersey milk to be profitable, was 2.63, 7.28, 9.95, and $12.37 \%$ at $25,50,75$, and $100 \%$ Jersey milk, respectively. Including Jersey milk did not affect the quantity of whey butter and powder produced. Although further research is needed to ascertain the amount of additional profit that would be found on a commercial scale, the results indicate that using Jersey milk for Cheddar cheese making would lead to an improvement in profit for the cheese makers, especially at higher inclusion rates.
\end{abstract}

Key words: Jersey milk, Cheddar cheese, profit, partial budget

\section{Short Communication}

An important factor influencing revenue in a cheesemaking plant is the yield of cheese from a set quantity of milk. Improving milk suitability for cheese making has been shown to be a valid way of improving cheese

Received August 8, 2014.

Accepted November 9, 2014.

${ }^{1}$ Corresponding author: j.h.bland@pgr.reading.ac.uk yield and thus revenue (Storry et al., 1983; Lucey and Kelly, 1994; Sundekilde et al., 2011). Jersey (JS) milk especially has been shown to be better suited for Cheddar cheese making than Holstein-Friesian (H-F) milk by improving cheese yield (Lundstedt, 1979; Geary et al., 2010) and reducing greenhouse gases and the environmental impact of Cheddar cheese production (Capper and Cady, 2012). However, its use commercially has been hindered by a presumed negative effect on cheese quality (Bliss, 1988) and the lack of information on the financial benefits of this method. A recent study by Bland et al. (2015) showed than when JS milk was included at different rates into H-F milk, the improvement in Cheddar cheese yield was not accompanied by detrimental changes in cheese quality. Cheese quality was evaluated through instrumental texture analysis, and professional grading scores at 3 and 8 mo and inclusion of Jersey milk did not significantly affect those parameters even if the fat content of the cheese produced with JS milk was increased. The lack of effect of the increased fat concentration on cheese texture was explained by the simultaneous reduction in moisture content and smaller casein micelle size increasing curd firmness and thus compensating for the higher fat content. Still, because of the higher price of JS milk compared with H-F milk and the difficulties of changing milk supply, the economic benefit needs to be determined before cheese makers will be confident in using JS milk more actively.

To determine the profitability of including JS milk in H-F milk supply for Cheddar cheese production, the increase in cheese yield must be weighed against increased milk costs. To explore these questions, partial budgeting was used in conjunction with sensitivity and break-even analysis. These methods are regularly used to compare alternative production practices in agriculture with limited data (Roth and Hyde, 2002).

In addition, because using JS milk was found to decrease the yield of fat and protein in whey because of an increase in protein and fat recovery (Bland et al., 2015), the financial effect on the coproducts of cheese making need to be evaluated. 
Partial budgeting is a method of comparing costs and benefits of alternative methods of production, in this case using different rates of inclusion of JS milk. The specific underlying assumption of our partial budgeting was that JS milk could significantly improve yield but would cost more to purchase. The model only encompasses the production stage and does not take into account the costs of transportation of milk and packaging and transportation of cheese. The fixed costs were also not included in the model because they are incurred regardless of the level of output. Furthermore, with the model being based on a set quantity of milk, starter and enzyme quantity were not modified by the addition of Jersey milk. Salt quantity was modified. However, it did not significantly influence the model, and thus, with the aim of simplification, it was not presented in this study. In addition, the revenue from whey products was not included in the partial budgeting because of the numerous uses of whey in the UK and the lack of an available market price for most of these products. Thus, the only changes seen in the partial budget were in cheese quantity and milk price.

Using JS milk was deemed more profitable than H-F milk if total positive effects were higher than total negative effects (Table 1). Total positive effect was calculated as increased incomes plus reduced costs. Total negative effect was calculated as increased costs plus reduced incomes. The additional profit $(\mathbf{A P})$ was given on a kilogram of milk basis and expressed as pound sterling and in parentheses US dollars using the 1-yr exchange-rate average of $£ 1=\$ 1.6290$ using the website www.Oanda.com.

The partial budgeting was performed using the data from the study by Bland et al. (unpublished data) based on one vat production of $100 \mathrm{~kg}$ of milk. In this study $\mathrm{H}-\mathrm{F}$ cheese making was compared with different inclusion rates of Jersey milk $(25,50,75$, and $100 \%)$ every month, over a year. The inclusions 25 and $75 \%$ were done on alternate months because of time constraints. The data set contained milk composition, cheese composition, and actual cheese yield. The average cheese composition was $34.3 \pm 0.3 \%, 23.4 \pm 0.4 \%$, and 37.56 $\pm 0.3 \%$ for fat, protein, and moisture content, respec- tively. Actual yield was calculated from the weight of milk placed in the vat and the weight of cheese after pressing and vacuum packing and expressed as kilogram of cheese per $100 \mathrm{~kg}$ of milk. Milk price was calculated from the milk contract offered by the commercial Cheddar cheese maker that the cheese-making process was based on (Alvis Bros Ltd., Bristol, UK). The determination of the milk price was based on season, SCC, and milk protein and fat content as commonly done in the UK. Cheese price was based on the average monthly wholesale price for mild Cheddar cheese on the UK market, over the period of the study as reported by the study of the Kantar Worldpanel (2013). The data used are presented in Table 2 and show mean and standard error for each inclusion rate. In total 36 scenarios were analyzed.

Sensitivity analysis was used to test which inputs variable had the greatest influence on the AP. The model inputs were defined as cheese price, cheese yield, and price for milk protein and milk fat. For the 36 scenarios, the effect of a fixed change $(1 \%)$ on the AP was calculated, one input at a time, and expressed as percentage change in AP.

The break-even analysis was carried out on the inputs that were found by the sensitivity analysis to have the most significant effect on the profitability of using JS milk. Using the Solver add-in (Frontline Systems Inc., Incline Village, NV) in Excel (Microsoft, Seattle, WA), the level of inputs that would give zero AP was calculated for all 36 scenarios.

The evaluation of whey revenue was based on the production of whey butter and whey powder for which UK market prices are available. Conversion of whey fat into whey butter, and whey nonfat solids into whey powder were calculated using the mass balance approach of DairyCo (2014a). Prices were determined using average monthly UK wholesale price for whey butter and whey powder over the period of the study as reported by DairyCo (2014b).

Data were subject to ANOVA and Tukey analysis using SPSS PASW Statistics 21.0 (SPSS Ltd., London, UK) to detect any statistical differences in AP and whey revenue between inclusion rates. Seasonal varia-

Table 1. Partial budget of the use of Jersey milk for Cheddar cheese making ${ }^{1}$

\begin{tabular}{ll}
\hline Positive effects & Negative effects \\
\hline Increased incomes $(\mathrm{J}$ cheese yield $\times$ cheese price; $£)$ & Increased costs $(\mathrm{J}$ milk quantity $\times \mathrm{J}$ milk price; $£)$ \\
Reduced costs $(\mathrm{H}-\mathrm{F}$ milk quantity $\times \mathrm{H}-\mathrm{F}$ milk price; $£)$ & Reduced incomes $(\mathrm{H}-\mathrm{F}$ cheese yield $\times$ cheese price; $£)$ \\
Total positive effects & Total negative effects \\
& $\begin{array}{l}\text { Per vat profit difference } \\
\end{array}$ \\
\hline
\end{tabular}

${ }^{1} \mathrm{~J}=$ Jersey; H-F = Holstein-Friesian. 
Table 2. Input variables, partial budgeting, sensitivity, and break-even analysis of the use of Jersey milk in Holstein-Friesian milk for Cheddar cheese making (mean \pm SE)

\begin{tabular}{|c|c|c|c|c|c|}
\hline \multirow[b]{2}{*}{ Item } & \multicolumn{5}{|c|}{ Percentage of Jersey milk in Holstein-Friesian milk } \\
\hline & $0(\mathrm{n}=12)$ & $25(\mathrm{n}=6)$ & $50(\mathrm{n}=12)$ & $75(\mathrm{n}=6)$ & $100(\mathrm{n}=12)$ \\
\hline Milk fat $(\%)$ & $3.94 \pm 0.07$ & $4.19 \pm 0.09$ & $4.70 \pm 0.05$ & $5.12 \pm 0.12$ & $5.43 \pm 0.10$ \\
\hline Milk protein content (\%) & $3.15 \pm 0.02$ & $3.26 \pm 0.03$ & $3.44 \pm 0.03$ & $3.58 \pm 0.06$ & $3.74 \pm 0.05$ \\
\hline Milk casein content $(\%)$ & $2.31 \pm 0.02$ & $2.39 \pm 0.03$ & $2.55 \pm 0.03$ & $2.66 \pm 0.05$ & $2.79 \pm 0.04$ \\
\hline Pence per kg of milk $(\mathrm{p} £)$ & $30.43 \pm 0.40(49.57 \phi)$ & $32.22 \pm 0.52(52.49 \phi)$ & $34.39 \pm 0.33(56.02 \phi)$ & $35.96 \pm 0.86(58.58 \phi)$ & $38.16 \pm 0.39(62.16 \phi)$ \\
\hline Cheese yield (kg/100 kg of milk) & $9.5 \pm 0.1$ & $10.3 \pm 0.2$ & $11.3 \pm 0.2$ & $12.0 \pm 0.2$ & $12.8 \pm 0.2$ \\
\hline Cheese price $(£ / \mathrm{kg})$ & $5.76 \pm 0.01(\$ 9.38)$ & $5.76 \pm 0.01(\$ 9.38)$ & $5.76 \pm 0.01(\$ 9.38)$ & $5.77 \pm 0.01(\$ 9.40)$ & $5.76 \pm 0.01(\$ 9.38)$ \\
\hline \multicolumn{6}{|l|}{ Additional profit } \\
\hline Per $\mathrm{kg}$ of milk $(\mathrm{p} £)$ & & $3.41 \pm 0.72^{\mathrm{a}}(5.55 \phi)$ & $6.44 \pm 0.77^{\mathrm{b}}(10.49 \phi)$ & $8.57 \pm 0.71^{\mathrm{c}}(13.98 \phi)$ & $11.18 \pm 0.75^{\mathrm{c}}(18.24 \phi)$ \\
\hline \multicolumn{6}{|l|}{ Sensitivity analysis ${ }^{1}$} \\
\hline Cheese yield decrease (\%) & & -17.38 & -10.24 & -8.04 & -6.51 \\
\hline Cheese price decrease $(\%)$ & & -1.42 & -1.66 & -1.59 & -1.65 \\
\hline Milk fat price increase (\%) & & -0.28 & -0.45 & -0.34 & -0.35 \\
\hline Milk protein price increase (\%) & & -0.28 & -0.3 & -0.23 & -0.26 \\
\hline \multicolumn{6}{|l|}{ Break-even point } \\
\hline Cheese yield ( $\mathrm{kg} / 100 \mathrm{~kg}$ of milk) & & $9.8 \pm 0.7^{\mathrm{a}}$ & $10.2 \pm 0.1^{\mathrm{ab}}$ & $10.6 \pm 0.2^{\mathrm{bc}}$ & $10.8 \pm 0.2^{\mathrm{c}}$ \\
\hline
\end{tabular}

${ }^{\mathrm{ac}}$ Means within a row with different superscripts differ $(P<0.05)$.

${ }^{1}$ Effect of $1 \%$ change in input on additional profit.

Table 3. Effect of Jersey milk in Holstein-Friesian milk on whey-products revenue (mean $\pm \mathrm{SE}$ )

\begin{tabular}{|c|c|c|c|c|c|}
\hline \multirow[b]{2}{*}{ Item } & \multicolumn{5}{|c|}{ Percentage of Jersey milk in Holstein-Friesian milk } \\
\hline & $0(\mathrm{n}=12)$ & $25(\mathrm{n}=6)$ & $50(\mathrm{n}=12)$ & $75(\mathrm{n}=6)$ & $100(\mathrm{n}=12)$ \\
\hline \multicolumn{6}{|l|}{ Whey } \\
\hline Yield (kg/100 kg of milk) & $87.5 \pm 0.28^{\mathrm{a}}$ & $87.5 \pm 0.56^{\mathrm{b}}$ & $85.93 \pm 0.27^{\mathrm{c}}$ & $84.91 \pm 0.38^{\mathrm{d}}$ & $84.33 \pm 0.35^{\mathrm{e}}$ \\
\hline Fat $(\%)$ & $0.70 \pm 0.03^{\mathrm{a}}$ & $0.60 \pm 0.03^{\mathrm{a}}$ & $0.60 \pm 0.02^{\mathrm{a}}$ & $0.62 \pm 0.02^{\mathrm{a}}$ & $0.65 \pm 0.02^{\mathrm{a}}$ \\
\hline Solids nonfat (\%) & $7.14 \pm 0.03^{\mathrm{a}}$ & $7.12 \pm 0.02^{\mathrm{a}}$ & $6.63 \pm 0.07^{\mathrm{a}}$ & $7.42 \pm 0.03^{\mathrm{a}}$ & $7.52 \pm 0.04^{\mathrm{a}}$ \\
\hline Butter (kg/100 kg of milk) & $0.008 \pm 0.000^{\mathrm{a}}$ & $0.007 \pm 0.000^{\mathrm{a}}$ & $0.007 \pm 0.000^{\mathrm{a}}$ & $0.007 \pm 0.000^{\mathrm{a}}$ & $0.007 \pm 0.000^{\mathrm{a}}$ \\
\hline Powder (kg/100 kg of milk) & $6.32 \pm 0.04^{\mathrm{a}}$ & $6.31 \pm 0.05^{\mathrm{a}}$ & $6.33 \pm 0.03^{\mathrm{a}}$ & $6.34 \pm 0.04^{\mathrm{a}}$ & $6.40 \pm 0.04^{\mathrm{a}}$ \\
\hline \multicolumn{6}{|l|}{ Price $(£ / \mathrm{kg})$} \\
\hline Butter & $3.01 \pm 0.11(\$ 4.90)$ & $2.95 \pm 0.20(\$ 4.80)$ & $3.01 \pm 0.11(\$ 4.90)$ & $2.98 \pm 0.16(\$ 4.85)$ & $2.96 \pm 0.23(\$ 4.82)$ \\
\hline Powder & $0.82 \pm 0.00(\$ 1.33)$ & $0.83 \pm 0.00(\$ 1.35)$ & $0.82 \pm 0.00(\$ 1.34)$ & $0.82 \pm 0.01(\$ 1.34)$ & $0.82 \pm 0.01(\$ 1.33)$ \\
\hline \multicolumn{6}{|l|}{ Revenue ( $£ / 100 \mathrm{~kg}$ of milk) } \\
\hline Butter & $2.05 \pm 0.17^{\mathrm{a}}(\$ 3.34)$ & $1.87 \pm 0.17^{\mathrm{a}}(\$ 3.05)$ & $1.80 \pm 0.07^{\mathrm{a}}(\$ 3.04)$ & $1.75 \pm 0.12^{\mathrm{a}}(\$ 2.85)$ & $1.78 \pm 0.08^{\mathrm{a}}(\$ 2.90)$ \\
\hline Powder & $5.19 \pm 0.7^{\mathrm{a}}(\$ 8.45)$ & $5.21 \pm 0.09^{\mathrm{a}}(\$ 8.48)$ & $5.23 \pm 0.05^{\mathrm{a}}(\$ 8.52)$ & $5.18 \pm 0.09^{\mathrm{a}}(\$ 8.43)$ & $5.26 \pm 0.06^{\mathrm{a}}(\$ 8.56)$ \\
\hline Total & $7.24 \pm 0.23^{\mathrm{a}}(\$ 11.79)$ & $7.09 \pm 0.2^{\mathrm{a}}(\$ 11.55)$ & $7.02 \pm 0.12^{\mathrm{a}}(\$ 11.44)$ & $6.93 \pm 0.19^{\mathrm{a}}(\$ 11.29)$ & $7.04 \pm 0.13^{\mathrm{a}}(\$ 11.46)$ \\
\hline
\end{tabular}


tion effects were tested the same way. Differences were considered significant at $P<0.05$.

A positive AP per vat and per kilogram of milk was found for each inclusion rate (Table 2). This indicates that the improvement in cheese yield resulting from the use of JS milk compensates for its higher milk price, and inclusion was more profitable than H-F milk. In addition, a positive quadratic trend was found between AP and percentage of JS milk $\left(\mathrm{R}^{2}=0.998, P<0.001\right)$. Thus, to maximize Cheddar cheese-making profit, the largest amount of JS milk possible should be used. This held true throughout the year; no difference in AP was observed between seasons $(P<0.01)$.

The results of the sensitivity analysis, presented in Table 2, showed that cheese yield had the most important effect on AP. A negative trend was found between JS milk inclusion rate and the percentage decrease in AP bought by a lower cheese yield $\left(\mathrm{R}^{2}=0.983, P<\right.$ 0.001). Thus, at a high-JS-milk inclusion rate AP was less affected than at a lower inclusion rate, again, supporting the point that a high level of JS milk should be used for Cheddar cheese making.

The second most important variable was cheese price. However, it did not put profit at risk. Volatility month to month was low $(0.00 \%$ over the period of the study), and even when the lowest cheese price seen since January 2010, £5.18 (\$8.44) per kilogram (Kantar Worldpanel, 2013), was used for the partial budgeting, the AP was still positive $[2.86 \pm 0.64(4.66 \phi), 5.38 \pm 0.70$ $(8.76 \phi), 7.16 \pm 0.69(11.66 \phi)$, and $9.27 \pm 0.66(15.10 \phi)$ pence per kilogram of milk for 25, 50, 75, and $100 \%$ JS milk, respectively]. Similarly, price for milk fat and protein had a small effect on AP.

The break-even analysis was carried out on cheese yield because it was the input that had the most important effect on profitability. The level of cheese yield that would give zero AP, meaning the profit would be equal to using only H-F milk, is given in Table 2 . The use of JS milk would result in a loss of profit only if the increase in cheese yield was less than 2.63, 7.2, 9.95, and $12.36 \%$ for each JS-milk inclusion rate. Past research has found, using Van Slyke yield equation, 100\% JS milk to improves Cheddar cheese yield by 17.74 to 36\% (Lundstedt, 1979; Geary et al., 2010; Capper and Cady, 2012; Bland et al., 2015), which is higher than the break-even point; thus, it is unlikely that using Jersey milk would result in a loss of profit.

Including JS milk did not influence whey composition overall, and the reduction in whey quantity (Table 3 ) did not affect the quantity of whey butter and whey powder produced. Thus, no difference in revenue was found. However, because of the difference in price of JS milk, this would cause a reduction in the AP, to $2.53 \pm$ $0.73(4.12 \phi), 5.04 \pm 0.76(8.20 \phi), 6.76 \pm 0.64(11.01 \phi)$, and $8.96 \pm 0.74(14.59 \phi)$ pence per kilogram of milk for $25,50,75$, and $100 \%$ JS milk, respectively.

Including JS milk in H-F milk for Cheddar cheese production was shown through partial budgeting to increase profit. The level of AP was increased when a high percentage of JS milk was used and was also shown to be less sensitive to a decrease in cheese yield. Cheese yield had the most important effect on the level of AP, but the cheese yields would have to be significantly lower than those found in this study and previous reports for JS milk not to be profitable. Changes in cheese and milk price had only a small effect on AP and were deemed not to put the profitability of using JS milk at risk.

When the revenue from whey butter and powder was included in the partial budgeting, the AP remained positive but was reduced because Jersey milk did not influence the production of whey products but was more expensive.

Additional studies on the effect of JS milk on Cheddar cheese yield, especially on a commercial scale in which production efficiency is higher, would bring higher certainty regarding the amount of AP that could be expected by cheese makers from the use of JS milk.

\section{ACKNOWLEDGMENTS}

Funding for this research was provided by UK Jersey, the Dartington Cattle Breeding Trust, the Royal Bath and West of England Society, West Country Dairy Award, and the Pocock Memorial trust.

\section{REFERENCES}

Bland, J. H., C. C. Fagan, and A. S. Grandison. 2015. Effect of blending Jersey and Holstein-Friesian milk on Cheddar cheese processing, composition, and quality. J. Dairy Sci. 98:1-8. http://dx.doi. org $/ 10.3168 /$ jds.2014-8433.

Bliss, K. 1988. Practical Cheesemaking. Crowood Press Ltd., Wiltshire, UK.

Capper, J. L., and R. A. Cady. 2012. A comparison of the environmental impact of Jersey compared with Holstein milk for cheese production. J. Dairy Sci. 95:165-176.

DairyCo. 2014a. Review of dairy market indicators. Agriculture and horticulture development board. Accessed Dec. 3, 2014. http:// www.dairyco.org.uk/resources-library/market-information/adhocreports/dairy-market-indicators-review/\#.VDZB7_IdVGY.

DairyCo. 2014b. Milk prices-Actual milk price equivalent and milk for cheese volume equivalent (2014). Agriculture and horticulture development board. Accessed Dec. 3, 2014. http://www.dairyco.org. uk/resources-library/market-information/milk-prices-contracts/ market-indicators/\#.VDZDkfldVGY.

Geary, U., N. Lopez-Villalobos, D. J. Garrick, and L. Shalloo. 2010. Development and application of a processing model for the Irish dairy industry. J. Dairy Sci. 93:5091-5100.

Kantar Worldpanel. 2013. Kantar Retail Cheese Market - Retail \& Consumer Data - Great Britain July 2013. Accessed Dec. 3, 2014. http:// www.dairyco.org.uk/resources-library/market-information/dairysales-consumption/kantar-worldpanel-cheese/\#.Uy1LL_vKM.

Lucey, J. A. J., and J. Kelly. 1994. Cheese yield. Int. J. Dairy Technol. 47:1-14. 
Lundstedt, E. 1979. Factors affecting the yield of cheese. Dairy Ind. Int. $4: 21-23$.

Roth, S., and J. Hyde. 2002. Partial Budgeting for Agricultural Businesses. Pennsylvania State University, University Park, PA.

Storry, J. E., A. S. Grandison, D. Millard, A. J. Owen, and G. D. Ford. 1983. Chemical composition and coagulating properties of renneted milks from different breeds and species of ruminant. J. Dairy Res. 50:215-229.
Sundekilde, U. K., P. D. Frederiksen, M. R. Clausen, L. B. Larsen, and H. C. Bertram. 2011. Relationship between the metabolite profile and technological properties of bovine milk from two dairy breeds elucidated by NMR-based metabolomics. J. Agric. Food Chem. 59:7360-7367. 